\title{
DEMOGRAPHIC VARIABLES VERSUS PHYSICAL ACTIVITY LEVEL OF THE NAŁĘCZÓW HEALTH RESORT VISITORS
}

\author{
Agata Pocztarska, Józef Bergier \\ Pope John Paul II State School of Higher Education in Biała Podlaska, \\ Department of Physical Education and Physiotherapy
}

Pocztarska A., Bergier J. (2015), Demographic variables versus physical activity level of the Nałęczów Health Resort visitors. Health Problems of Civilization, 4 (9), p. 54-60.

Summary: Introduction. Low levels of physical activity in the society have been observed in Poland for many years, especially in case of elder people. It is surprising that, in the era of intensified development of diseases of affluence, many people still do not recognize health benefits that result from regular physical exercise.

Materials and method. 622 health resort visitors who participated in the research in the Nałęczów Health Resort were divided into groups based on socio-demographic status in order to recognize the determinants of their physical activity. A short version of International Physical Activity Questionnaire (IPAQ) was used to estimate the level of physical activity. Results. Health resort visitors were characterized by a relatively low level of general physical activity, and walking was a predominant type of exercise. Surprisingly, professional status did not significantly differentiate participants' physical activity. However, especially participants from small villages and towns with primary education presented a low level of physical activity. These were mostly pensioners and persons of disadvantaged groups with lower income.

Conclusions. Most of health resort visitors represent low level of physical activity which cannot be significantly and statistically differentiated by any demographic variable.

Keywords: physical activity, IPAQ, demographic variables, social status, health resort visitors

\section{Introduction}

It is generally known that, apart from biologic factors, social factors also have influence on people's health condition. Thus, 'health' is defined as a state of complete physical, mental, and social well-being and not merely the absence of disease or infirmity (WHO 2002). Therefore, all actions undertaken by a person in everyday life should aim at shaping the health potential.

Among the determinants of health, which include: biological factors, health care system, social and environmental influences, an important role is played by psychosocial environment including: social and economic status, employment, individual behaviours and lifestyle that consists of all behaviours and actions profitable for health, and those posing a risk to health (Kulik 2014). Hence, physical activity is a key element of a healthy lifestyle, and a factor influencing a successful development and health of the individual.

There is no doubt that, a healthy, physically fit person shows greater motivation in work, satisfaction with life, and has a possibility to pursue dreams and aspirations. In contrast, low physical activity may be a cause of higher mortality that results from coronary artery disease, diabetes mellitus type 2 and cancer (Jethon, Wierzbicka-Damska 2005, Rożek et al. 2006). According to the World Health Organization (WHO 2004), lack of physical activity causes the death of 2 million people every year. It is the reason why, in the National Health Programme, a strategic aim was adopted, namely: "The improvement of the population health and the quality of life related to it" by increasing the physical activity in society and shaping motivation, knowledge, and skills regarding healthy lifestyle (Narodowy Program Zdrowia [National Health Programme] 2007-2015).

\footnotetext{
Address for correspondence: Agata Pocztarska, Pope John II State School of Higher Education in Biała Podlaska, Sidorska 105, 21-500, Biała Podlaska, phone: +48 8334499 00, e-mail: agata.pocztarska@interia.pl

Tables: 0 Figures: 6 References: 23 Full-text PDF www.hpc.edu.pl Copyright (c) Pope John Paul II State School of Higher Education in Biała Podlaska, Sidorska 95/97,21-500 Biała Podlaska Indexation: Index Copernicus, AGRO, ProQuest, Polish Medical Bibliography, Polish Ministry of Science and Higher Education. This is an open-access article distributed under the terms of the Creative Common Attribution Non-commercial license (http://creativecommons.org/licenses/by-nc/3.0), which permits use, distribution and reproduction in any medium, provided the original works is properly cited, the use is non-commercial and is otherwise in compliance with the license.
} 


\section{Aim of the study}

Main aim of this study was to estimate the level of physical activity in health resort visitors and to recognize whether the included demographic variables, such as: education, place of residence, professional status and amount of income, differentiate the level of physical activity in population.

\section{Materials and method}

Research was conducted in Nałęczów Health Resort in 2012.622 health resort complex visitors were examined: "Książę Józef", "Stare Łazienki", "Fortunat", "Batorówka", and Cardiology Hospital. The sample included: 313 women and 309 men, age 27-90 $(x=61.9 \pm 9.1)$. Participants were divided on the basis of: level of education (primary, secondary, higher), professional status (white collar worker, blue collar worker, unemployed, retired, and pensioner) place of residence (city, village) and financial situation (amount of income).

The physical activity has been assessed on the basis of the short version of the International Physical Activity Questionnaire - IPAQ. The form of the questionnaire has been chosen due to its diagnosticity (Craig et al. 2003). Its standardization and versatility allow to estimate the physical activity of people aged 15-69. IPAQ includes physical activities performed during 7 typical, preceding the survey days and lasting continuously for not less than 10 minutes. The survey concerned the physical activity of the patients in the week preceding their arrival to the Spa Nałęczów.

The short version of the questionnaire used in the study includes 7 questions regarding any type of physical activity connected to professional work, everyday life and rest. On this basis the information about the amount of time spent during the day for intense physical activity, moderate walking and in a sitting position has been obtained.

Every listed type of the physical activity has been expressed in MET-minutes/week (metabolic energy turnover) ${ }^{1}$ units. On the basis of the resulting average of the physical activity expressed in MET-minutes/week unites the subjects of the study were classified into one of three levels of physical activity.

A high level of activity has been observed among people who during 3 or more days performed intense physical effort, reaching at least 1500 MET-minutes/week or during 7 or more days undertook any of three types of physical exercises exceeding 3000 MET-minutes/week.

Moderate level of physical activity has been observed among people, who completed one of the three categories: 3 or more days of intense physical activity lasting at least 20 minutes per day; 5 or more days of moderate physical activity or walking lasting at least 30 minutes per day; 5 or more days of any combination of the types of physical activity exceeding 600 MET-minutes/week. Low physical activity has been detected among people, who did not perform any physical activity or did not meet the conditions of moderate or high activity level (Biernat 2011).

Statistical calculations of survey data were performed by means of the program Statistica 7.1. arithmetic means $(x)$, standard deviation (s) and coefficients of variation $(V)$ have been calculated. The test for qualitative variables Pearson chi-square $(\chi 2)$, assuming the level of statistical significance $p=0.05$, has been used for the analysis of differentiation of physical activity in relation to patients' demographic variables.

\section{Results}

Total - weekly - physical activity of the patients averaged 739.8 \pm 819.3 MET-minutes/week. Walking was the clearly dominating type of physical activity $500.5 \pm 638.8$ MET-minutes/week. Moderate activity accounted for $189.4 \pm 336.5$ MET-minutes/week, while intensive only for $49.9 \pm 210.1$ MET-minutes/week, which seems to be a natural phenomenon among the ill and the aged people (Figure 1). 


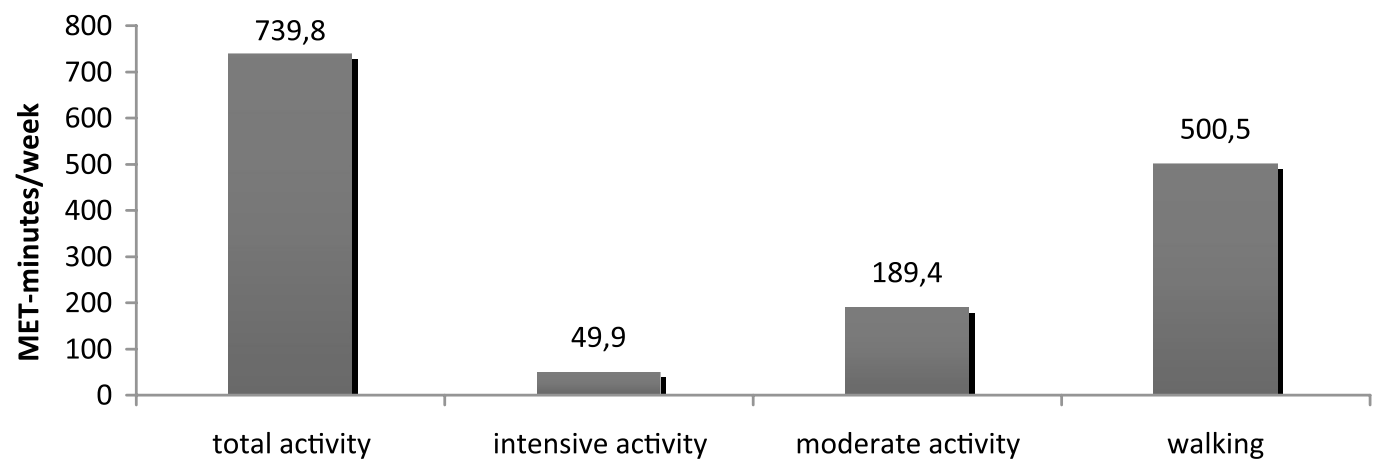

Figure 1. The types of the physical activity of the patients of Spa Nałęczów

Most of the patients showed low level of the physical activity (60\%), the rest of them showed moderate level (39.5\%) and only 3 people (0.5\%) declared intense activity (Figure 2 ).

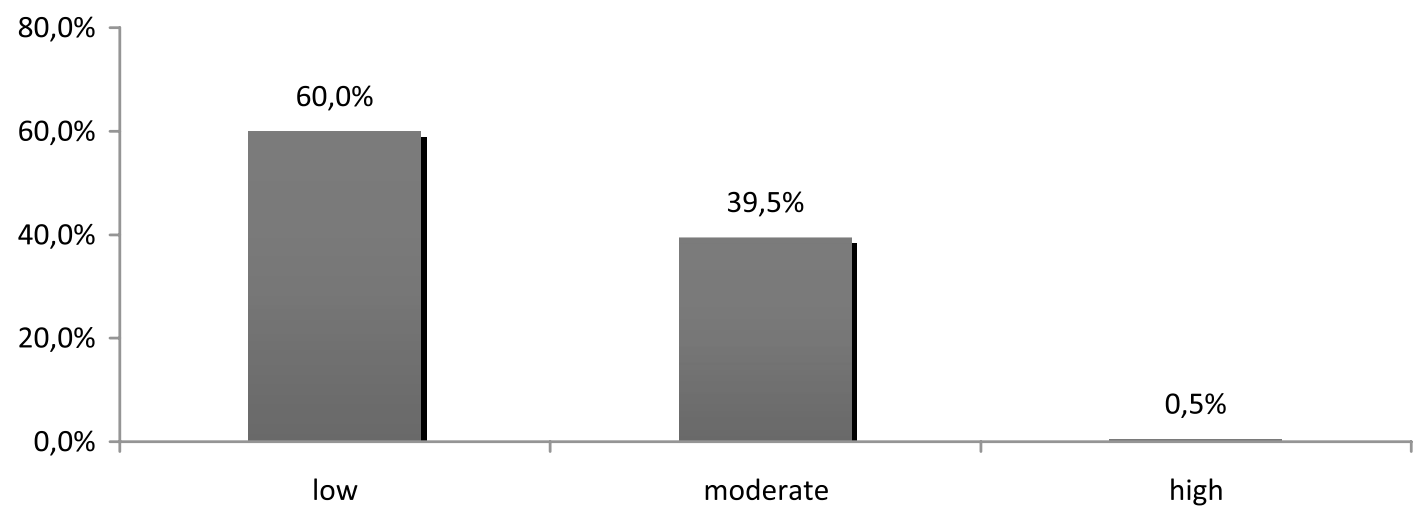

Figure 2. The level of the physical activity among Spa Nałęczów patients

Among the determinants: education, place of residence, professional status and income level have been included. Statistically significant differences in the level of the physical activity of the patients due to demographics (Figure $3-6$ ) have not been found. However, the analysis of the level of physical activity depending on the education has indicated, that the low level of the physical activity has been shown among the respondents with the basic (67.9\%) and secondary (61.7\%) education. The moderate level of physical activity has been revealed among the majority of respondents with higher education (44.5\%).

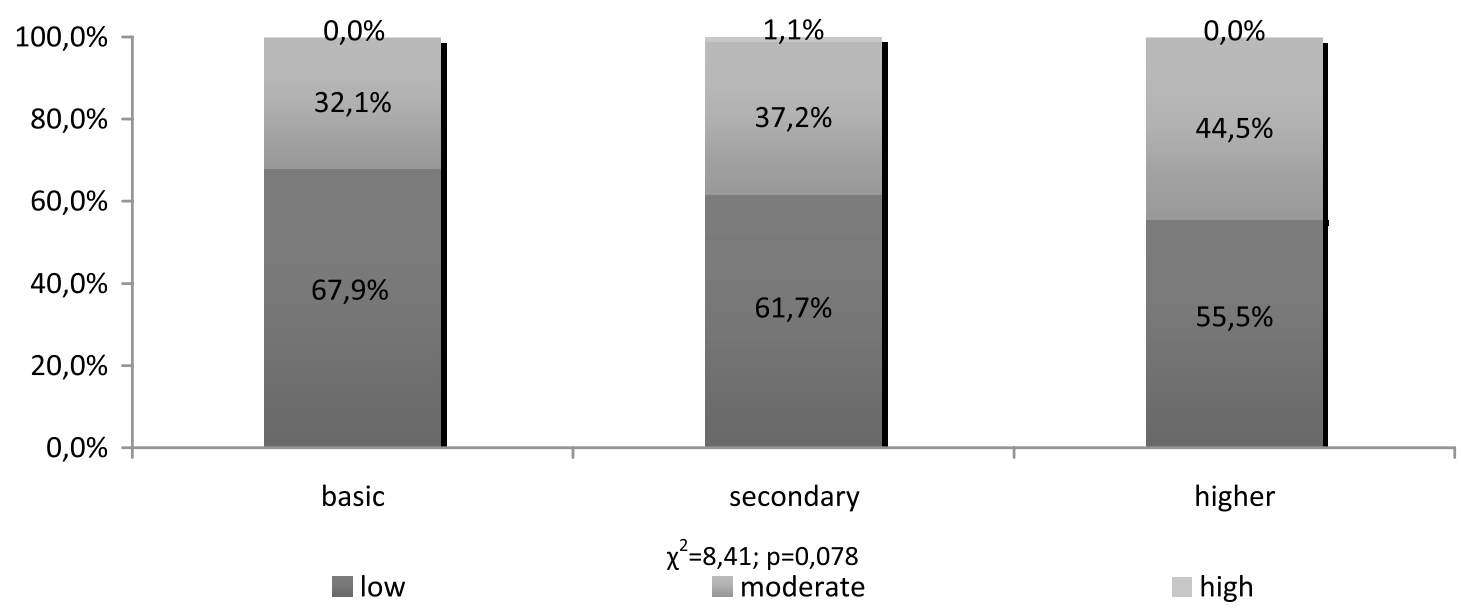

Figure 3. Education and physical activity of Nałęczów health resort visitors 
There is no significant correlation between the physical activity level and place of residence (fig. 4). However, a low physical activity level is seen primarily in cities with population of 10 to 20 thousand $(67.9 \%)$ and in rural areas (61.5\%). A vast majority of spa visitors with moderate physical activity level live in cities with population of 10,000 or less $(52.9 \%)$. All three visitors with high physical activity level $(1.0 \%)$ were residents of cities with population above 20,000 .

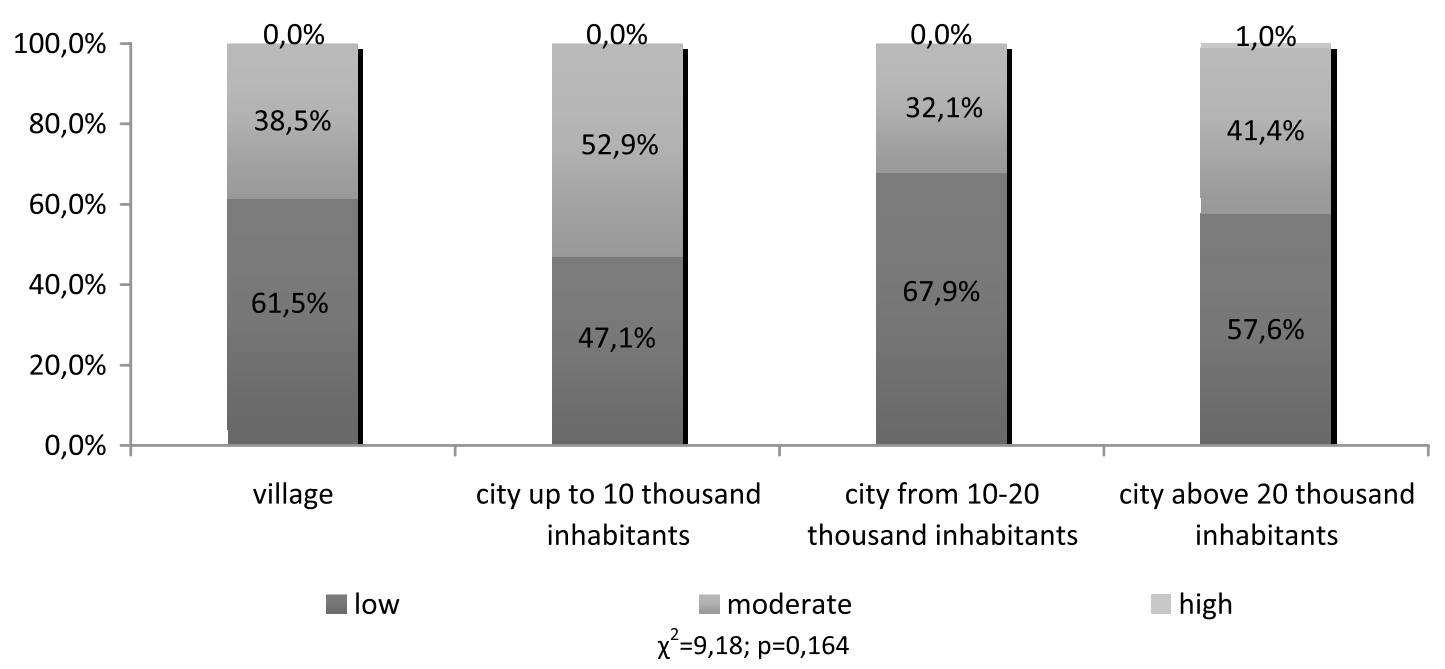

Figure 4. Place of residence and physical activity of Nałęczów health resort visitors

Considering the professional status of the respondents (knowledge workers, manual workers, the unemployed and pensioners) there are no statistically significant differences in their physical activity level (fig. 5). 5) It's important to indicate that low physical activity level is most common among annuitants (68.1\%) and pensioners (61.8\%), followed by white-collar workers (57.0\%), unemployed (55.6\%) and manual workers (55.1\%). Moderate physical activity level was highest among the unemployed (44.4\%), and lowest for the annuitants (31.9\%) Only three pensioners were highly physically active $(1.3 \%)$.

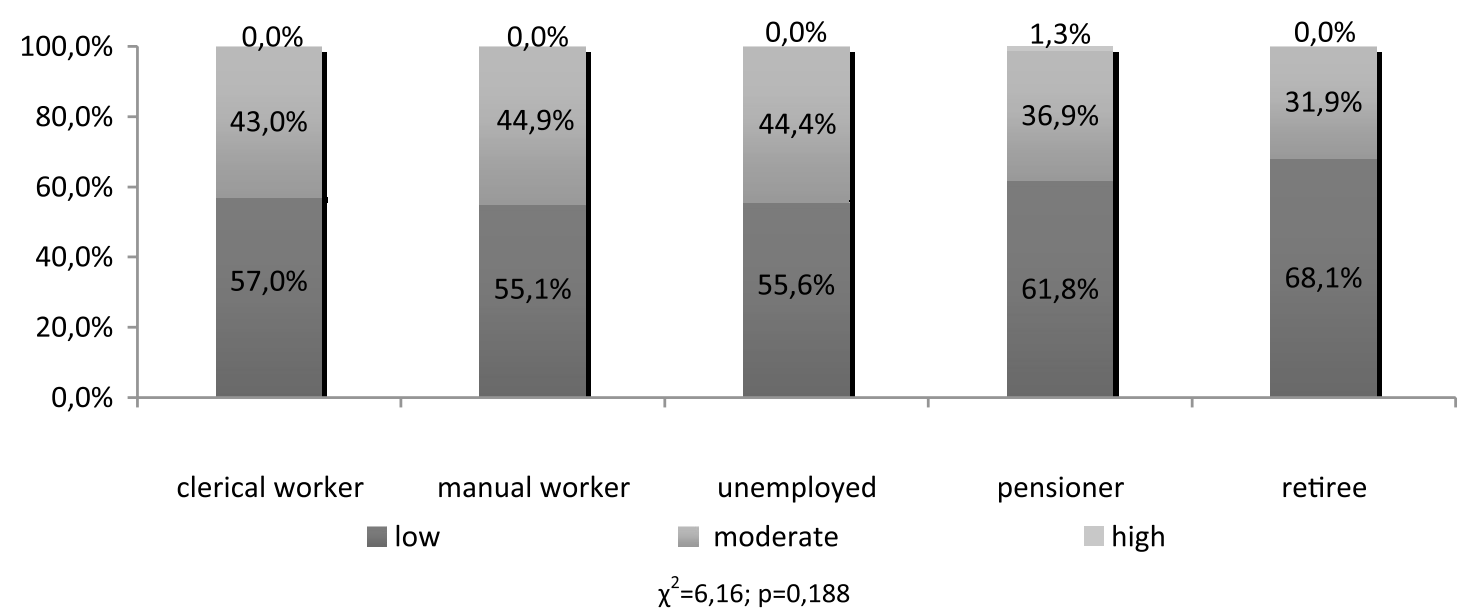

Figure 5. Professional status and physical activity of Nałęczów health resort visitors

The analysis did not reveal any statistically significant differences in relation to the salary (fig. 6). It's worth noting that both visitors with the smallest and the largest income had a low physical activity level $(65.6 \%$ and $55.7 \%)$. Moderate physical activity level was the lowest for the visitors with the smallest income (33.6\%) and the highest for visitors with the largest income (44.3\%). 


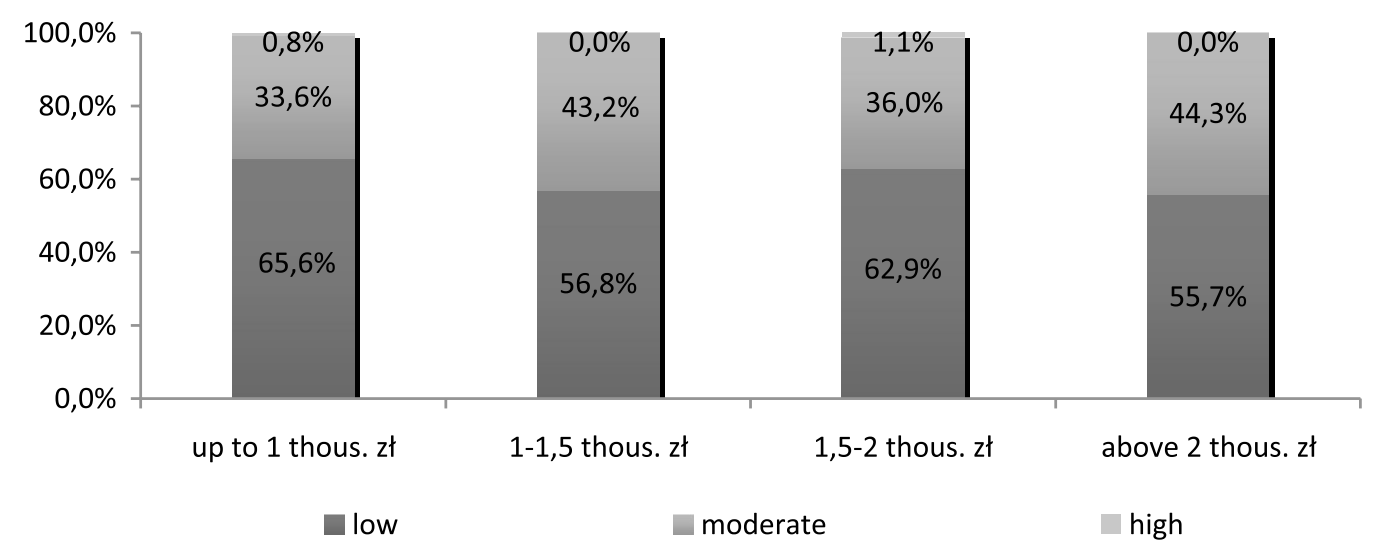

Figure 6. Income and physical activity levels of Nałęczów health resort visitors

\section{Discussion}

Regular physical activity is greatly beneficial for mental and social health, for example by improving mood and general well-being, alleviating depression and anxiety, helping in self-acceptance and self-confidence, improving social skills and attitude, gaining new experiences, skills and knowledge, delaying the ageing process and by supporting an independent lifestyle (Corbin 2007, Parnicka 2006, Osinski 2011)

Although the Polish society knows about the benefits of being physically active (Siwiński 2000), its physical activity level is quite low (Drygas 2001, Drygas et al. 2001, 2005, Maciatowicz 2003, CSO 2009, Piątkowska 2010). Participation of adult Poles in active recreation is negligible compared to other European countries. Only $10 \%$ of adults are engaged in any form of physical activity that by type and intensity is enough to satisfy basic physiological needs of a human organism (Drygas et al. 2001, CSO 2009, National Health program for years 2007 to 2015).

The designated level of physical activity of the spa visitors equals 739.8 MET-minutes/week - which is the lowest index achieved in present studies. Walking is a predominant activity - 500.5 MET-minutes/week, and moderate activity - 189.4 MET-minutes/week, but only 49.9 MET accounted for an intensive activity, which seems to be expected for sick and rather old people. What's interesting is that a similar value of physical activity has been estimated for the employees of self-government administration in Warsaw - 877.1 MET-minutes/week (Biernat 2011). On the basis of those findings it can be concluded that physical activity of spa visitors is similar to people associated with certain socio-professional groups. Current range of MET-minutes/week domestic research among the adults is stretched between 1420 - 5644 MET-minutes/week (Bergier 2012). The surveyed visitors were clearly physically inactive (less than 600 MET-minutes/week) - 60\%, moderately active (from 600 to 1500 MET-minutes / week) - 39.5\% and three people with high level of activity $-0.5 \%$. Walking, the predominant type of physical activity among visitors - 500.5 MET-minutes/week, is also common for certain professional groups, e.g. the employees of self-government administration - 499.5 MET-minutes/week, and it is even lower for hypermarket employees - 293.8 MET-minutes/week (Biernat 2011).

In order to find demographic variables which determine the physical activity level, the most commonly used factors in research were taken into account: education, place of residence, professional status and income level. What is surprising is the fact that none of the investigated variables determined the physical activity level of visitors to a significant extent. It should be noted that the most prevalent research on physical activity among residents of Warsaw done to date (Biernat 2011) only indicated a relation between the physical activity and education, which only concerned one of the sixteen professional groups, namely the academic teachers. The Biernat research shows that a low level of physical activity can be noted mostly among people with elementary education (56\%). Moderate activity can be seen mostly among people with the highest education (52\%), and the highest level of activity by the people with elementary (12\%) and higher education (11\%). Similarly, the lowest level of physical activity was most common among the visitors with elementary education. Moderate activity was mostly seen among respondents with higher education, and the highest activity among those with secondary education. The research confirms that with the increase of education the percentage of people physically active also goes up. According to Kostka, the highest consistency of physical activity is seen among people with higher education (33\%), followed by those with secondary education (20\%), and only $4 \%$ for people with elementary education (Kostka 1997). It has been shown that the most commonly practised forms of activity are rehabilitation and therapeutic exercises as well as hiking. The conclusion is that education increases the 
number of people who practice these exercises and the frequency of doing it (Derczyński 2001, Kostka 1997). According to the results of Centre for Public Opinion Research (CBOS), 79\% of people with elementary education did not practice any form of physical activity. Sedentary lifestyle was indicated by $34 \%$ of population with secondary education and 26\% with higher education (Kostka 1997). Despite not having determined any statistically significant differences in the physical activity level in relation to residency of visitors, it is worth mentioning that people with low level of activity live in medium-sized cities - 10-20 thousand (67.9\%) and rural areas (61.5\%). Similar results were achieved by Woynarowska (2001), who proved that physically inactive people mostly live in rural areas (50.8\%). Visitors of Nałęczów who are moderately active mainly live in small towns with population of 10,000 or less (52.9\%). In contrast, the only people with a high physical activity level are the residents of cities with population of 20,000 or more. The test results are not reflected in other studies conducted the adult Polish society, which prove that consistency in exercising to improve physical fitness and health is the domain of residents of large cities (more than 500.000 inhabitants) (Derczyński 2001, Kostka 1997). Place of residence also affects the types of practised exercises. Rehabilitation and therapeutic exercises are practised more often by residents of large cities. In contrast, people in small towns and villages are far more likely to ride a bike, also for transportation. Social status and income level are visibly differentiating the physical activity level of the visitors. Among the respondents a low physical activity level was the most common for annuitants (68.1\%) and pensioners (61.8\%). The highest percentage of people who practice moderate level of physical activity are the manual workers (44.9\%) and the unemployed (44.4\%). Low physical activity level was mainly seen among the visitors with the lowest income (65.6\%). However, a higher activity level could be seen among people of high economic status (44.3\%). Similar correlations were confirmed by other authors. It has been stated that people employed in high vocational and economic jobs, mainly the white-collar workers, have shown a higher physical activity than people in worse situation (Alejziak 2000, Cybulska 2003). It also supports the fact that the pensioners have a relatively low physical activity level (Woynarowska 2001).

We can agree that a passive attitude to physical exercises determines affiliation to a particular social group. But these are not the demographic factors included in the research that should become the basic premise by a long shot, but rather the confidence of the surveyed people about the importance of physical activity for health and shaping one's behaviour to care about physical fitness that should incline them to practice it.

\section{Conclusions}

1. Most of the spa visitors were not physically active. Walking was the predominant type of the entirety of physical activity.

2. Physical activity level was not influenced by demographic variables to any significant extent. However, it is worth noting that low level of activity was mainly seen among visitors with elementary education, residents of medium-sized cities with population of 10 to 20 thousand inhabitants, annuitants and people with the lowest income.

\section{References:}

1. Alejziak W. (2000), Aktywność turystyczna elit finansowych $w$ Polsce (wstępny raport $z$ badań), W: J. Wyrzykowski (red.), Studia nad czasem wolnym mieszkańców dużych miast Polski i jego wykorzystaniem na rekreację ruchowq i turystykę. AWF Wrocław.

2. Bergier J. (2012), Aktywność fizyczna społeczeństwa - współczesny problem (przegląd badań). Człowiek i Zdrowie, vol. IV, no. 1, p. 3-12.

3. Biernat E. (2011), Aktywność fizyczna mieszkańców Warszawy. Na przykładzie wybranych grup zawodowych. Oficyna Wydawnicza. Szkoła Główna Handlowa w Warszawie.

4. Corbin B., Welk G., Corbin W., Welk K. (2006), Fitness i wellness. Kondycja, sprawność, zdrowie. Zysk i S-ka, Poznań.

5. Craig C.L., Marshall A.L., Sjostrom M., Bauman A.E., Booth M.L., Ainsworth B.E., Pratt M., Ekelund U., Yngve A., Sallis J.F., Oja P. (2003), International physical activity questionnaire 12 country reliability and validity. Medicine and Science in Sports and Exercise, no. 35 (8), p. 1381-1395.

6. Cybulska A. (2003), O aktywności fizycznej Polaków. Komunikat z badań. Aktualne problemy i wydarzenia. CBOS, Warszawa.

7. Derczyński W. (2001), Troska o sprawność fizycznq - sport, rekreacja, rehabilitacja. Aktualne problemy i wydarzenia. Komunikat z badań. CBOS, Warszawa.

8. Drygas W., Bielecki W. (2001), Stan zdrowia, postawy i zachowania zdrowotne mieszkańców Torunia. Raport 
z badań wykonanych w ramach programu CINDI WHO, Łódź.

9. Drygas W., Skiba A., Bielecki W. (2001), Ocena aktywności fizycznej mieszkańców sześciu krajów europejskich. Projekt "Bridight the East - West Health GAP". Medycyna Sportowa, no 5, p.169-174.

10. Główny Urząd Statystyczny (2009), Uczestnictwo Polaków w sporcie i rekreacji ruchowej w $2008 \mathrm{r}$. Warszawa.

11. Jethon Z., Wierzbicka-Damska I. (2005), Możliwości przeciwdziałania powstawaniu nadwagi i otyłości za pomoca ćwiczeń fizycznych, W: Znaczenie aktywności ruchowej dla zdrowia. Studia i Monografie. E. MurawskaCiałowicz, M. Zatoń (red.). Akademia Wychowania Fizycznego, Wrocław, no. 75, p. 83-103.

12. Kostka R. (1997), Zdrowy styl życia po polsku, W: Wartości, praca, zakupy. O stylu życia Polaków. M. Falkowska (red.), CBOS, Warszawa.

13. Kulik T. (2014), Koncepcja zdrowia w medycynie, W: Zdrowie Publiczne. T. Kulik, A. Pacian (red.), Wydawnictwo Lekarskie PZWL, Warszawa.

14. Maciatowicz J. (2003), Ruch fizyczny o charakterze wytrzymałościowym (bieg) zapobiega starzeniu się, leczy z patologicznych chorób serca. Medycyna Sportowa, vol. 19, no. 4, p. 156-164.

15. Ministerstwo Zdrowia i Opieki Społecznej (2007), Narodowy program Zdrowia na lata 2007 - 2015. http://www. mz.gov.pl/wwwfiles/ma_struktura/docs/zal_urm_nz_90_15052007p.pdf

16. Osiński W. (2002), Aktywność fizyczna podejmowana przez osoby w podeszłym wieku. Antropomotoryka, no 24, p. 3-24.

17. Parnicka U. (2006), Aktywność fizyczna na tle innych form czasu wolnego kobiet czynnych zawodowo, W: D. Nałęcka, M. Bytniewski (red.), Teoria i praktyka rekreacji ruchowej. Państwowa Wyższa Szkoła Zawodowa, Biała Podlaska, p. 44-51.

18. Piątkowska M. (2010), Uczestnictwo Polaków w aktywności fizycznej w porównaniu do innych krajów Unii Europejskiej. W: K. Buśko, J. Charzewska, K. Kaczanowski (red.), Współczesne metody pomiaru aktywności, sprawności i wydolności człowieka. Akademia Wychowania Fizycznego, Warszawa, p. 38-57.

19. Rożek K., Ostrowska B., Piechura J., R., Ignasiak Z., Sławińska T., Dąbrowska G., (2006), Systematic physical activity as a positive health indicator in scoliotic children. Polish Journal of Environmental Studies, no. 15, p. 28-42.

20. Siwiński W. (2000), Wychowanie do rekreacji ruchowej. Pedagogika kultury fizycznej w zarysie. Akademia Wychowania Fizycznego, Warszawa.

21. WHO (2004), Global strategy on Diet, Physical Activity and Health. Geneva. www.who.int/dietphysicalactivity/ en/.

22. World Health Organization (2002), Growing Older - Staying Well: Ageing and physical activity in everyday life. www. whqlibdoc.who.int/hq/WHO_HPR_AHE_98.1.pdf

23. Woynarowska B. (2001), Kształtowanie prozdrowotnego życia ludności w Polsce. Zagrożenia i szanse, W: Z. Żukowska, R. Żukowski (red.), Zdrowie - ruch - fair play. AWF, Klub Fair Play PKOL, Warszawa.

Submitted: 11.08 .2015

Accepted: 25.11.2015 